\title{
Analisis Hubungan Kompensasi dengan Kinerja Karyawan PT. Bima Sakti Pertiwi Pekanbaru
}

\author{
MUHAMMAD ALI AQSA \\ Sekolah Tinggi Ilmu Ekonomi Riau \\ Jln. HR Subrantas KM 12 No. 57 Panam Pekanbaru Telp. (0761) 63237 Fax. (0761) 63237 \\ E-mail : muh.ali.aqsa@gmail.com
}

\begin{abstract}
This research was conducted at PT. Bima Sakti Pertiwi Pekanbaru. The purpose of the implementation of this study is to determine how big the relationship between the variable compensation with performance variables. The number of samples in this study were as many as 32 respondents, because the sample in this study amounted to under 100 then researchers used the technique of saturated samples in the determination of the sample. Data analysis techniques in this study using descriptive and quantitative methods. Where on the quantitative method, the researcher uses a simple correlation. Where obtained results of 0.746 . which means both variables have a strong and positive relationship. The results of this study indicate that there is a strong and positive relationship between compensation and employee performance at PT. Bima Sakti Pertiwi Pekanbaru.
\end{abstract}

Keywords: compensation, Performance

Di era digital dan perkembangan teknologi yang begitu pesat saat ini, menuntut perusahaan untuk meningkatkan kinerja perusahaan melalui peningkatan kinerja karyawan. Perusahaan dapat memaksimalkan sumber daya yang dimiliki baik sumber daya berwujud dan tidak berwujud. Peningkatan sumber daya berwujud dapat dilakukan dengan memberikan pelatihan dan pengembangan sumber daya, gaji, bonus dan kompensasi. Keberadaan sumber daya manusia di dalam suatu perusahaan memegang peranan sangat penting dan memiliki posisi strategis diantara sumber daya lainnya yang dimiliki oleh perusahaan. Tenaga kerja mempunyai potensi yang besar untuk menjalankan aktivitas perusahaan. Potensi setiap sumber daya manusia yang ada dalam perusahaan harus dapat dimanfaatkan dengan semaksimal mungkin oleh perusahaan sehingga mampu memberikan output yang sesuai dengan tujuan organisasi yang telah ditetapkan. Tercapainya tujuan perusahaan tidak hanya tergantung pada peralatan modern, sarana dan prasarana yang lengkap, tetapi justru lebih tergantung pada manusia yang melaksanakan pekerjaan tersebut. Keberhasilan suatu organisasi sangat dipengaruhi oleh kinerja individu karyawannya. Setiap organisasi baik perusahaan maupun instansi lain akan selalu berusaha untuk meningkatkan kinerja para karyawan.

Dengan semakin ketatnya persaingan di dunia bisnis pada era digital teknologi saat ini, menuntut perusahaan untuk terus melakukan perubahanperubahan kebijakan guna mempertahankan asset berharga yang mereka miliki yakni sumber daya manusia. Salah satu upaya yang dilakukan perusahaan untuk meningkatkan kinerja karyawan adalah dengan selalu memperhatikan kebutuhan karyawan dalam hal ini memaksimalkan pemberian kompensasi kepada karyawan. Kompensasi merupakan salah satu hal yang sangat penting bagi karyawan, karena besarnya kompensasi merupakan cerminan untuk mengukur kinerja karyawan secara individu dan mengukur kinerja perusahaan secara keseluruhan. Besar kecilnya kompensasi yang di terima karyawan sangat mempengaruhi kinerja, prestasi kerja, produktivitas kerja dan 
tingkat kepuasan kerja karyawan yang mana pada gilirannya akan berdampak pada tingkat kedisiplinan kerja karyawan.

PT. Bima Sakti Pertiwi yang bergerak di bidang pusat perbelanjaan dalam hal ini sebagai badan pengelola Mal Pekanbaru yang berlokasi di PekanbaruRiau. PT. Bima Sakti Pertiwi dibangun dan mulai berdiri pada tahun 2001 sampai sekarang dan berpredikat sebagai salah satu pusat perbelanjaan terbesar di Riau. Dikarenakan semakin terbukanya pasar dan majunya media elektronik dan cetak serta dengan adanya peluang bisnis yang menguntungkan maka mendorong munculnya perusahaan- perusahaan yang bergerak di bidang yang sama sebagai kompetitor. Keadaan seperti ini berdampak bertambah luasnya jangkauan dari para pesaing yang berskala besar dan tentu saja pasar yang diperebutkan juga semakin kompetitif. Diantaranya adalah Mal Ciputra yang dibangun pada tahun 2004 dan mal SKA menyusul pada tahun yang sama. Hal ini sedikit menggeser pangsa pasar pusat perbelanjaan di Pekanbaru khususnya dan Riau umumnya. Disamping adanya pusat perbelanjaan terdahulu yang sudah berdiri yaitu Plaza Citra dan Plaza Senapelan. Tentu saja hal ini sangat berpengaruh pada jumlah pengunjung yang datang ke Mal Pekanbaru.

Pemberian kompensasi pada PT. Bima Sakti Pertiwi mengalami perubahan setiap tahunnya dan pemberian kompensasi didasarkan pada pangkat dan jabatan yang dimiliki oleh karyawan. Selain kompensasi finansial, PT. Bima Sakti Pertiwi juga memberikan kompensasi non finansial dalm bentuk penghargaan, pelatihan, promosi jabatan serta tunjangan Ketenaga kerjaan. Data menunjukkan kompensasi lainnya yang diterima oleh karyawan PT. Bima Sakti Pertiwi dalam kurun waktu tahun 2012 sampai dengan tahun 2016. Selain kompensasi diatas, perusahaan juga memberikan fasilitas tunjangan BPJS baik itu ketenagakerjaan maupun kesehatan kepada seluruh karyawan PT. Bima Sakti pertiwi Pekanbaru. Selain itu perusahaan juga memberikan fasilitas penunjang bagi karyawan yaitu fasilitas parkir gratis pada gedung mal pekanbaru yang juga sebagai kantor PT. Bima Sakti Pertiwi Pekanbaru. Ditengah-tengah usaha perusahaan dalam berpacu dengan waktu untuk mencapai target untuk dapat bersaing dengan kompetitor, perusahaan memiliki masalah yaitu berkurangnya jumlah karyawan dari tahun ke tahun, hal ini jika dibiarkan lambat laun akan berpengaruh pada efektifitas kinerja perusahaan. Masalah ini tidak terlepas dari kebijakan perusahaan kepada karyawannya dalam memberikan upah atau konpensasi.

Menurut Manullang (2001:198), manajemen sumber daya manusia adalah seni dan ilmu pengadaan, pengembangan dan pemanfaatan sumber daya manusia sehingga tujuan organisasi direalisasikan secara daya guna dan adanya kegairahan kerja dari semua tenaga kerja. Menurut Edwin B. Flippo dalam Hani Handoko (2012:3), manajemen personalia adalah perencanaan, pengorganisasian, pengarahan dan pengawasan kegiatankegiatan pengadaan, pengembangan, pemberian kompensasi, pengintegrasian, pemeliharaan dan pelepasan sumber daya manusia agar tercapai berbagai tujuan individu, organisasi dan masyarakat. Kegairahan kerja dari semua tenaga kerja. (Manullang, 2002:198) Manajemen Sumber Daya Manusia adalah ilmu dan seni mengatur hubungan dan peranan tenaga kerja agar efektif dan efisien membantu terwujudnya tujuan perusahaan, karyawan dan masyarakat. (Melayu S.P. Hasibuan, 2012:10).

Manajemen Sumber Daya Manusia adalah suatu kegiatan pengelolaan yang meliputi pendayagunaan, pengembangan, penilaian, pemberian balas jasa sebagai individu anggota organisasi atau perusahaan bisnis. (Sadili Samsudin, 2006:22).

Menurut Malayu S.P Hasibuan (2009:24), Kinerja adalah penghormatan

p.ISSN: $2407-800 \mathrm{X}$

e.ISSN: $2541-4356$ 
jasa,jasmani dan pikiran untuk menghasilkan barang- barang atau jasa-jasa dengan memperoleh imbalan prestasi tertentu. Wirawan (2012:5) mendefinisikan kinerja adalah keluaran yang dihasilkan oleh fungsi-fungsi atau indikator-indikator suatu pekerjaan atau suatu profesi dalam waktu tertentu. Sedangkan Wilson Bangun (2012:231), menyebutkan bahwa kinerja adalah hasil pekerjaan yang dicapai karyawan berdasarkan persyaratanpersyaratan pekerjaan.

Selain itu menurut Sedermayanti dalam Edrick Leonardo dan Fransisca Andreani (2015:29), kinerja merupakan hasil kerja seorang karyawan, sebuah proses manajemen secara keseluruhan, dimana hasil kerja seorang tersebut harus dapat ditunjukkan buktinya secara konkrit dan dapat diukur. Kinerja menurut Torang dalam Edrick Leonardo dan Fransisca Andreani (2015:30), adalah kuantitas dan kualitas hasil kerja individu atau sekelompok di dalam perusahaan dalam melaksanakan tugas pokok dan fungsi yang berpedoman pada norma, standar operasional prosedur, kriteria dan ukuran yang telah ditetapkan atau yang berlaku dalam perusahaan. Penilaian kinerja adalah proses yang dilakukan organisasi untuk mengevaluasi dan menilai keberhasilan karyawan dalam melaksanakan tugasnya (Wilson Bangun 2012:231).

Menurut Wilson Bangun (2012:232) tujuan dan manfaat penilaian kinerja yaitu sebagai berikut: Evaluasi antar individu dalam organisasi; Pengembangan diri

setiap individu dalam organisasi; Pemeliharaan sistem; Dokumentasi.

Standar pekerjaan dapat ditentukan dari isi suatu pekerjaan, dapat dijadikan sebagai dasar penilaian setiap pekerjaan. Untuk memudahkan penilaian kinerja karyawan, standar pekerjaan harus dapat diukur dan dipahami secara jelas. Menurut Robert L Mathis (2006:78) yang menjadi indikator dalam mengukur kinerja atas prestasi karyawan adalah sebagai berikut : Kuantitas kerja, yaitu volume kerja yang dihasilkan dalam kondisi normal. Indikatornya adalah jumlah hasil kerja dan produktifitas; Kualitas kerja, yaitu dapat berupa kerapian, ketelitian dan keterkaitan hasil dengan tidak mengabaikan volume pekerjaan. Indikatornya adalah potensi diri, hasi lkerja yang optimal dan proses kerja; Pemanfaatan waktu, yaitu penggunaan masa kerja yang disesuaikan dengan kebijaksanaan perusahaan atau lenbaga pemerintah. Indikatornya adalah produktifitas dan keterampilan; Kerja sama, yaitu kemampuan menangani hubungan dengan orang lain dalam pekerjaan. Indikatornya adalah pemecahan masalah dan kerja sama; Kehadiran, yaitu kedisiplinan dalam mematuhi tingkat absensi yang telah disesuaikan dengan kebijaksanaan perusahaan. Indikatornya adalah absensi, masuk dan pulang tepat waktu.

Menurut Panggabean dalam Usman Fauzi (2014:173), kompensasi dapat didefinisikan sebagai setiap bentuk penghargaan yang diberikan kepada karyawan sebagai balas jasa atas kontribusi yang mereka berikan kepada organisasi. Selanjutnya Saydam (2008:181) mengemukakan bahwa kompensasi adalah sebagai bentuk balas jasa perusahaan terhadap pengorbanan waktu, tenaga, dan pikiran yang telah diberikan mereka (karyawan) kepada perusahaan. Menurut Handoko (2012:155), kompensasi adalah segala sesuatu yang diterima karyawan sebagai balas jasa atas kerja mereka. Dalam pengertian ini kompensasi diartikan sebagai semua bentuk penghargaan yang diterima karyawan atas kinerja baik mereka selama ini, baik berupa kompensasi finansial seperti gaji pokok, insentif, bonus dan maupun berupa kompensasi non finansial seperti adanya peluang promosi bagi karyawan yang berpotensi.

Menurut Siahaan dalam Rendi Efendi Putra (2001:17), kompensasi

p.ISSN: $2407-800 X \quad$ e.ISSN: 2541-4356 
dibedakan atas kompensasi finansial dan kompensasi nonfinansial. Menurut Sofiyandi dalam Edrick Leonardo dan Fransisca Andreani (2015:28), kompensasi finansial adalah kompensasi yang diberikan kepada karyawan sebagai imbalan atas pekerjaan yang dilakukan untuk perusahaan. Sutrisno dalam Edrick Leonardo dan Fransisca Andreani (2015:28), menyatakan bahwa kompensasi finansial adalah kompensasi yang langsung diserahkan oleh perusahaan terhadap karyawannya dalam bentuk upah atau bonus, sementara kompensasi non finansial adalah kompensasi yang tidak dapat dirasakan secara langsung oleh karyawan. Kompensasi non finansial diberikan oleh perusahaan sebagai usaha dari perusahaan untuk meningkatkan kesejahteraan karyawannya. Kompensasi non finansial bisa berupa pujian dari pimpinan, fasilitas yang diberikan perusahaan, lingkungan kerja perusahaan.

Adapun tujuan kompensasi menurut Hasibuan (2009 : 121), adalah sebagai berikut: Ikatan kerja sama, Kepuasan kerja, Pengadaan efektif, Motivasi, Stabilitas karyawan, Disiplin,Pengaruh serikat buruh. Indikator-indikator kompensasi menurut Nurmansyah (2011:199) diantaranya : Gaji, Adalah pendapatan yang diterima seseorang atas balas jasa yang diberikan kepadanya. Tunjangan, Adalah pendapatan tambahan selain gaji yang diterima seseorang seperti asuransi kesehatan dan jiwa, liburan yang ditanggung perusahaan, program pensiun dan lain sebagainya. Fasilitas, Adalah segala sesuatu yang diterima seseorang untuk melancarkan pekerjaan seperti fasilitas kendaraan, fasilitas keanggotaan klub,tempat parkir khusus dan lain sebagainya. Insentif, Adalah pendapatan tambahan yang diperolah karena adanya perbedaan prestasi kerja.

\section{METODE}

Menurut Arikunto (2010 : 173),
populasi adalah keseluruhan subyek penelitian. Jadi pengertian populasi bias diartikan secara umum yaitu bukan hanya sekedar jumlah yang ada pada pokok atau subyek yang akan dipelajari, tetapi meliputi keseluruhan dari karakteristik atau sifat yang dimiliki oleh subyek yang akan diteliti. Adapun yang menjadi populasi dalam penelitian ini adalah karyawan PT. Bima Sakti Pertiwi Pekanbaru tahun 2016 yang berjumlah 32 orang. Menurut Arikunto (2010 : 173), sampel adalah sebahagian dari populasi yang dijadikan sebagai obyek dan sumber data serta informasi dalam penelitian yang dianggap mewakili dari suatu penelitian. Semua populasi dijadikan sampel. Untuk menentukan sampel yang akan digunakan dalam penelitian yang menggunakan metode sensus yaitu seluruh populasi dijadikan sampel, dimana dalam penelitian ini sampel berjumlah 32 orang.

Teknik analisis data pada penelitian ini dengan menggunakan pendekatan deskriptif dan kuantitatif. Dimana pada pendekatan kuantitatif, peneliti menggunakan metode korelasi sederhana. Dimana menurut Sugiyono (2014:87) korelasi adalah metode pertautan atau metode penelitian yang berusaha menghubung-hubungkan antara satu unsur/elemen dengan unsur/elemen lain untuk menciptakan bentuk dan wujud baru yang berbeda dengan sebelumnya.

Pada penelitian ini, peneliti menggunakan metode analisis korelasi rank spearman, dimana instrumen ini digunakan untuk mengukur kuat lemahnya hubungan antar variabel yang berbeda.

\section{HASIL}

Berdasarkan hasil deksriptif, diperoleh hasil bahwa bahwa rata-rata skor total yang diperoleh tentang kinerja karyawan PT. Bima Sakti Pertiwi Pekanbaru adalah sebesar 3,97. Kondisi ini menggambarkan bahwa jawaban responden tentang kinerja karyawan selama ini memuaskan. Sementara pada hasil uji variabel kompensasi di peroleh rata-rata 
sebesar 3,91. Kondisi ini menggambarkan bahwa jawaban responden tentang kompensasi yang diberikan perusahaan selama ini memuaskan.

Berdasarkan hasil pengujian uji korelasi sederhana melalui metode rank spearman, dimana antara variabel kompensasi dengan variabel kinerja adalah sebesar 0.746 dengan arah positif. Hal ini berarti hubungan kedua variabel berada pada rank $0.600-0.799$, dan dari hasil uji diatas juga menunjukkan nilai positif, Hal ini berarti perubahan terhadap variabel kompensasi akan diikuti oleh variabel kinerja. Dan berdasarkan hasil uji diatas juga dapat dijelaskan bahwa hubungan variabel kompensasi dan variabel kinerja memiliki hubungan yang kuat dan searah. Untuk mengetahui besarnya hubungan antar kedua variabel, maka dilakukan perhitungan uji koefisien determinasi sebagaimana dapat dilihat pada perhitungan. Dari hasil perhitungan koefisien determinasi, dapat dijelaskan bahwa hubungan antara variabel kompensasi dengan variabel kinerja karyawan adalah sebesar $55.6 \%$, sedangkan sisanya dipengaruhi oleh variabel lain yang tidak diteliti pada penelitian ini.

\section{PEMBAHASAN}

Berdasarkan hasil penelitian yang telah dilakukan diatas, maka pembahasan dalam penelitian ini adalah bahwa terdapat hubungan yang kuat dan positif antara kompensasi dengan kinerja Karyawan Pada PT. Bima Sakti Pertiwi Pekanbaru. Hal ini sejalan dengan pendapat Mahmudi dalam Diana Hertati (2009:435) menyatakan bahwa kompensasi yang tinggi menuntut prestasi, kompetensi dan kualitas yang tinggi. Dengan adanya pemberian kompensasi yang tinggi maka diharaapkan karyawan memiliki kinerja yang tinggi. Sama hal nya dengan yang disampaikan oleh Daft dalam Diana Hertati (2009:435) dimana menyatakan bahwa sebagian besar organisasi yang ada saat ini mengembangkan rencana rencana kompensasi berdasarkan pada standar pembayaran pasa kinerja untuk Jurnal Daya Saing (Vol. 4, No. 2 Jun 2018) meningkatkan produktivitas dan memotong biaya buruh dalam lingkungan persaingan global.

\section{SIMPULAN}

Berdasarkan dari hasil pengujian yang telah dilakukan pada penelitian dengan judul analisis hubungan antara kompensasi dengan kinerja karyawan pada Bima Sakti Pertiwi Pekanbaru, maka dapat di tarik beberapa kesimpulan, diantaranya : Berdasarkan Uji Rank Spearman, diperoleh hasil sebesar 0.746, yang mana hasil ini menjelaskan bahwa terdapat hubungan yang kuat antara variabel kompensasi dengan kinerja karyawan pada karyawan pada PT. Bima Sakti Pertiwi Pekanbaru. Berdasarkan uji koefisien determinasi, diperolah hasil bahwa hubungan antara kompensasi dengan kinerja karyawan sebesar $55.6 \%$, sedangkan sisanya dipengaruhi oleh variabel lain yang tidak di kaji pada penelitian ini.

\section{DAFTAR RUJUKAN}

Arikunto, Suharmisi, 2010. Prosedur penelitian suatu pendekatan praktek. Rineka Cipta Jakarta.

Bangun, Wilson. 2012. Manajemen Sumber Daya Manusia. Jakarta. Erlangga.

Bustanul. 2012. Pengaruh Kompensasi Terhadap Kinerja Pegawai Pada Badan Perencanaan Pembangunan Daerah Kabupaten Kuantan Singingi. Sekolah Tinggi Ilmu Ekonomi Riau.

Dessler, G. 1998. Manajemen Sumber Daya Manusia, Yogyakarta : BPFE.

Fathony, Abdurrahmat. 2006. Manajemen Sumber Daya Manusia. Jakarta : Rineka Cipta.

Fauzi, Usman. 2014. Pengaruh Kompensasi Terhadap Kinerja Karyawan Pada p.ISSN: 2407-800X e.ISSN: 2541-4356 
PT. Trakindo Utama Samarinda. Ejurnal Ilmu Administrasi Bisnis Vol 2 No 3. Fakultas Ilmu Sosial dan Ilmu Politik.Universitas Mulawarman.

Wildan, Ikhsanul, 2014. Skripsi.Pengaruh Kompensasi Terhadap Kinerja Guru di SMK Terpadu Darussalam Pangean Kuantan Singingi. Sekolah Tinggi Ilmu Ekonomi Riau.

Hidayat, Riyan, 2015. Skripsi.Pengaruh Kompensasi Terhadap Karyawan Giant Ekstra Panam Pekanbaru. Sekolah Tinggi Ilmu Ekonomi Riau.

Hasibuan, Malayu S.P. 1999. Manajemen Dasar, Pengertian Dan Masalah. Buku I Jakarta : CV. Haji Masagung. . 2009. Manajemen Sumber Daya Manusia. Jakarta PT. Bumi Aksara.

Handoko, Hani. 2012. Manajemen Personalia Dan Sumber Daya Manusia Edisi 2. Yogyakarta : BPFE.
Hertati, Diana. 2009. Hubungan Kompensasi dengan Kinerja Karyawan di VICO Indonesia Company Muara Badak Kalimantan Timur. Jurnal Aplikasi Manajemen Volume 7 Nomor 2. Universitas Pembangunan Negeri "Veteran" Jawa Timur.

Leonardo, Edrick; Andreani, F. 2015. Pengaruh Pemberian Kompensasi Terhadap Kinerja Karyawan Pada Pt. Kopanitia. Jurnal Agora Vol 3 No 2. Universitas Kristen Petra.

Manullang. 2001. Dasar Dasar Manajemen, Yogyakarta : Gadjah Mada University Press. 